\title{
Treatment of systemic sclerosis with D-penicillamine
}

\section{A new method of observing the effects of treatment}

\author{
RODNEY BLUESTONE, R. GRAHAME,* THE LATE V. HOLLOWAY, AND \\ P. J. L. HOLT \\ Department of Medicine, Royal Postgraduate Medical School, London
}

The pathogenisis of scleroderma is unknown. Histologically it is initially characterized by a gross excess of collagen arranged in irregular bundles, these being later replaced by fibrous tissue and calcification. Harris and Sjoerdsma (1966) have shown the proportion of soluble collagen in this skin to be less than in normal skin. The report by Nimni (1965), showing that the sulphur-containing amino acid penicillamine increases the conversion of insoluble to soluble collagen by disrupting and inhibiting the formation of intermolecular bonds, suggested the possible therapeutic application of this drug in systemic sclerosis (scleroderma). This has been confirmed by Harris and Sjoerdsma (1966), who found a decrease in insoluble and an increase in the poorly cross-linked soluble collagen after short-term administration of penicillamine to patients with scleroderma. By more prolonged dosage there is therefore a possibility of arresting or reversing the widespread tissue sclerosis of this usually slowly progressive disease.
We report here the results of a trial of D-penicillamine in eleven patients with systemic sclerosis using subjective and objective criteria of response.

\section{Patients studied and methods}

Ten women aged 28 to 72 (mean 49.5) years and one man aged 62 years were treated. Their clinical features are shown in Table I. The known duration of their disease ranged from 8 months to 20 years and included all grades of severity. The degree of systemic involvement was investigated in all patients and forms the basis of separate reports (Bluestone, MacMahon, and Dawson, 1968; Godfrey, Bluestone, and Higgs, 1968; Thompson, Bluestone, Bywaters, Dorling, and Johnson, 1968).

For the purposes of this trial the following observations were used:

(1) Patients' subjective symptoms, in particular skin tightness and Raynaud's phenomenon.

(2) An estimate of the degree of clinical skin involvement, telangiectasia, and pigmentation.

Table I Clinical particulars of eleven patients. All had facial involvement

\begin{tabular}{|c|c|c|c|c|c|c|c|c|}
\hline \multirow{2}{*}{ Case No. } & \multirow{2}{*}{$\operatorname{Sex}$} & \multirow{2}{*}{$\begin{array}{l}\text { Age } \\
\text { (yrs) }\end{array}$} & \multirow{2}{*}{$\begin{array}{l}\text { Duration } \\
(y r s)\end{array}$} & \multirow{2}{*}{$\begin{array}{l}\text { Erythrocyte } \\
\text { sedimentation } \\
\text { rate } \\
\text { (Westergren) } \\
(\mathrm{mm} . / 1 \text { st hr) }\end{array}$} & \multicolumn{4}{|c|}{ Organs involved } \\
\hline & & & & & Skin & Lungs & Gut & Muscle \\
\hline $\begin{array}{r}1 \\
2 \\
3 \\
4 \\
5 \\
6 \\
7 \\
8 \\
9 \\
9 \\
10\end{array}$ & $\begin{array}{l}F \\
F \\
F \\
F \\
F \\
F \\
F \\
F \\
F \\
F\end{array}$ & $\begin{array}{l}28 \\
33 \\
34 \\
39 \\
42 \\
51 \\
63 \\
65 \\
66 \\
72\end{array}$ & $\begin{array}{r}1 \\
14 \\
6 \\
15 \\
12 \\
5 \\
1 \\
7 \\
5 \\
2 / 3\end{array}$ & $\begin{array}{r}11 \\
38 \\
14 \\
4 \\
14 \\
68 \\
10 \\
29 \\
25 \\
6\end{array}$ & $\begin{array}{l}\text { E } \\
\text { HAFT } \\
\text { HAF } \\
\text { HT } \\
\text { ET } \\
\text { E } \\
\text { HA } \\
\text { E } \\
\text { E } \\
\text { HA }\end{array}$ & $\begin{array}{l}\mathbf{X} \\
\mathbf{X} \\
\mathbf{X}\end{array}$ & $\begin{array}{l}\mathbf{X} \\
\mathbf{X} \\
\mathbf{X} \\
\mathbf{X} \\
\mathbf{X} \\
\mathbf{X} \\
\mathbf{X} \\
\mathbf{X} \\
\mathbf{X}\end{array}$ & $\mathbf{X}$ \\
\hline 11 & $\mathbf{M}$ & 62 & 20 & 58 & HAF & $\mathrm{X}$ & & \\
\hline
\end{tabular}

$E=$ extensive changes in limbs and trunk, $H=$ hand, $A=\operatorname{arm}, F=$ feet, $T=$ severe telangiectasia 


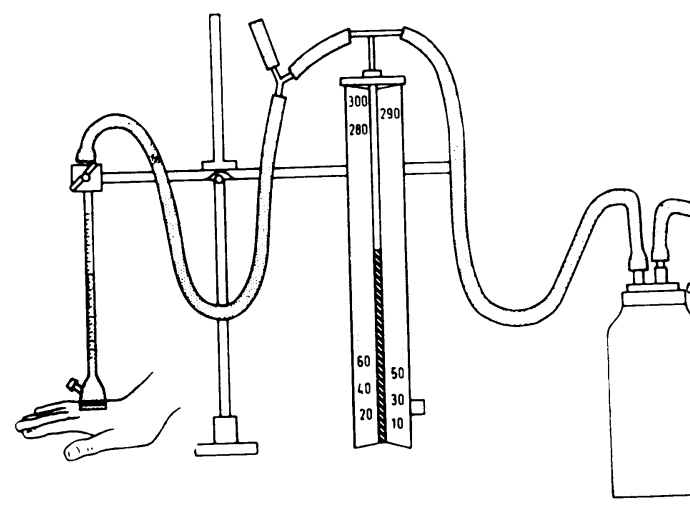

(3) The maximum degree of mouth opening in the horizontal and vertical direction was used as an index of perioral skin tethering.

(4) Tendon contractures if present were noted, and the degree of digital ulceration and the reactive hyperaemia times were used as a measure of digital ischaemia (Pickering, 1933).

(5) Maximum grip strengths (Savage, Davis, Chapman, Propert, Robertson, and Copeman 1958), writing-time, and palm-print areas (Ansell and Bywaters, 1953) were recorded. A change of over 30 per cent. in right or left palmar contact area for better or worse during the assessment period was considered significant.

In order to investigate more accurately the physical properties of the skin in this disease, a suction cup was applied to the intact skin of the dorsum of the right hand and the distortion produced in response to a series of pre-determined negative pressures was measured (Grahame and Holt, 1969) (Fig. 1). Applying the appropriate formulae (Tregear, 1966) for the in vitro diaphragm method for skin extensibility to the data so obtained enables stress (T) and strain (S) to be expressed in mathematical terms.* Where the skin thickness can be

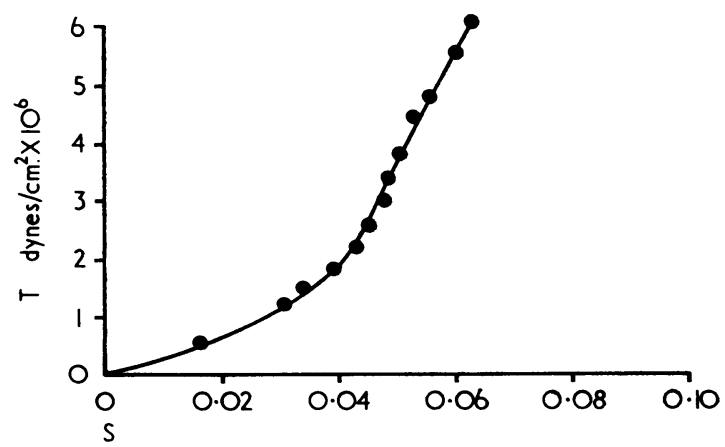

FIG. 2 In vivo stress/strain curve obtained from the forearm of a healthy young female subject. (Reproduced by permission of the editor and publishers of The Annals of Physical Medicine)

$$
\text { - T (Stress) }=\frac{p a^{2}\left(1+\frac{x^{2}}{a^{2}}\right)}{4 x d} \quad \mathrm{~S} \text { (Strain) }=\frac{2 x^{2}}{3 a^{2}\left(1+\frac{2 x^{2}}{a^{2}}\right)}
$$

where $p=$ pressure, $a=$ radius of circle of skin, $x=$ height of dome raised, $d=$ skin thickness.
FIG. 1 Apparatus for measuring skin elasticity.

established by the use of Harpenden calipers (Tanner and Whitehouse, 1955), the gradient (T/S) represents the Elastic Modulus (Y) for intact skin (Fig. 2). In scleroderma it is often not possible to measure skin thickness with calipers because of cutaneous tethering to underlying tissues, and formal measurement of skin elasticity is thus impossible. Nevertheless, in these circumstances, it is possible to obtain data for stress $\times$ thickness $(\mathrm{T} d)$ and strain (S) and thereby to construct a $\mathrm{T} d / \mathrm{S}$ curve.

With healthy skin the resultant $T d / S$ curve has a characteristic form. Initially there is considerable strain in response to comparatively little stress. This is due to the take-up of slack. After approximately 5 per cent. strain is achieved, further increases in stress result in relatively little increase in strain. From this point the relationship is virtually linear. The emergence of a stress/ strain curve the general shape of which conforms to the normal pattern (Fig. 2) depends on the unimpeded movement of the skin as a free diaphragm (Grahame, 1969). In scleroderma the skin tethering abolishes free movement and abnormally shaped curves result: viz. horizontal lines, U-shapes, and zig-zag shapes (Fig. 3). Presumably this is because the formulae used to calculate the results are inappropriate in any situation in which movement as a free diaphragm cannot occur. Thus the

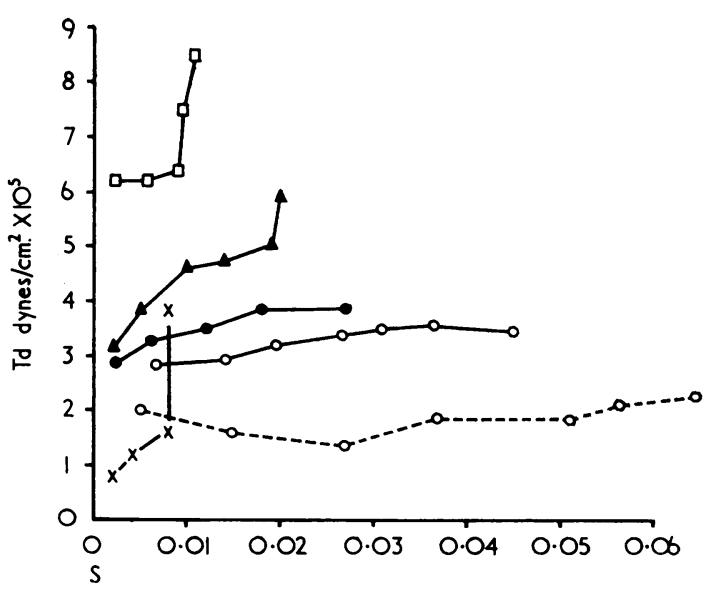

FIG. 3 In vivo stress/strain curves obtained from testing six patients with scleroderma before treatment. 
reversion to normal of a previously abnormal result obtained in testing the same area of skin implies a significant lessening in the degree of tethering.

Observations on the above clinical criteria were made at 3-monthly intervals for the duration of treatment and approximately 1 year after the end of treatment. In vivo skin elasticity was measured serially in ten patients. Collagen estimations were performed on pre- and posttreatment skin samples taken from adjacent sites on the dorsum of the hand in eight patients (these will be reported separately).

\section{Drug schedule}

D-penicillamine hydrochloride was started at a low dose (150 mg./day) incieasing gradually over the first month to a maximum tolerated dose of up to $3 \mathrm{~g}$./day. Pyridoxine $30 \mathrm{mg}$./day was given in addition, in view of the antivitamin $\mathbf{B}_{6}$ effect of penicillamine (Jaffe, Altman, and Merryman, 1964). Regular blood counts and urine tests were performed throughout the duration of treatment, to detect toxic effects such as thrombocytopenia or albuminuria.

\section{Results}

One patient (Case 6) died from her severe illness while abroad and the effect of treatment could not be assessed. A further patient (Case 8) had to stop treatment after a few days because of side-effects. These two patients are not included in the discussion. The remaining nine patients were treated for 5 to 15 months (mean 9.2) with maximum daily doses of 1.5 to $3 \mathrm{~g}$. (average $2 \cdot 4$ ). The results of therapy in these nine patients are shown in Table II.

\section{CLINICAL}

Most patients showed no change or a worsening in their clinical condition. One patient felt subjective improvement, and four clinical worsening. No patients showed clinical evidence of decreased skin sclerosis and in four the skin involvement, telangiectasia, and pigmentation were thought to have increased. Perioral skin tethering lessened in two patients and grew worse in five. Tendon contractures progressed in two patients. Digital ischaemia increased in three patients. These criteria were felt to be unreliable and of little use in assessment. Grip strength and writing time remained unaltered throughout.

Table II Results of skin elasticity and palm-print area tests

\begin{tabular}{|c|c|c|c|c|c|}
\hline \multirow{2}{*}{ Case No. } & \multirow{2}{*}{$\begin{array}{l}\text { Length of treatment } \\
\text { (mths) }\end{array}$} & \multirow{2}{*}{$\begin{array}{l}\text { Total dose } \\
(\mathrm{g} .)\end{array}$} & \multicolumn{3}{|c|}{ Skin elasticity (palm-print areas) } \\
\hline & & & Pre-treatment & End of treatment & Final assessment* \\
\hline 1 & 7 & 518 & $\mathbf{A}$ & $\begin{array}{l}\mathrm{N} \\
(\mathrm{NC})\end{array}$ & $\begin{array}{l}\mathbf{N} \\
(\mathbf{I})\end{array}$ \\
\hline 15 & 16 & 1,198 & $\mathbf{A}$ & $\begin{array}{l}\mathrm{N} \\
(\mathrm{NC})\end{array}$ & $\begin{array}{l}\mathbf{N} \\
\text { (I) }\end{array}$ \\
\hline 7 & 9 & 704 & A & $\begin{array}{l}\mathrm{N} \\
(\mathrm{NC})\end{array}$ & $\begin{array}{l}\mathbf{N} \\
(\mathbf{I})\end{array}$ \\
\hline 9 & 5 & 224 & $\mathbf{A}$ & $\begin{array}{l}\mathbf{N} \\
(\mathrm{NC})\end{array}$ & $\begin{array}{l}\text { A } \\
\text { (D) }\end{array}$ \\
\hline 11 & 10 & 501 & $\mathbf{A}$ & $\begin{array}{l}\mathbf{N} \\
(\mathrm{I})\end{array}$ & $\begin{array}{l}\text { A } \\
\text { (D) }\end{array}$ \\
\hline 10 & 11 & 628 & $\mathbf{A}$ & $\begin{array}{l}\mathrm{N} \\
(\mathrm{NC})\end{array}$ & \\
\hline 2 & 10 & 670 & $\mathbf{A}$ & (NC) & $\stackrel{\mathrm{A}}{(\mathrm{NC})}$ \\
\hline 8 & 5 wks & 26 & $\mathbf{A}$ & $\begin{array}{l}\mathrm{A} \\
(\mathrm{W})\end{array}$ & $\begin{array}{l}\text { A } \\
\text { (W) }\end{array}$ \\
\hline 3 & 6 & 1,034 & $\mathbf{A}$ & $\begin{array}{l}A \\
(W)\end{array}$ & \\
\hline 4 & 9 & 430 & $\mathbf{A}$ & $\stackrel{A}{(N C)}$ & \\
\hline 6 & Died at 4 months & & & & \\
\hline
\end{tabular}

Skin elasticity results above and palm-print results below in brackets

$\mathrm{A}=$ abnormal, $\mathbf{N}=$ normal, $\mathrm{NC}=$ no change, $\mathbf{I}=$ improved, $\mathbf{W}=$ worse, $\mathrm{D}=$ deteriorated

* At least 9 months after the end of treatment 


\section{SKIN ELASTICITY IN VIVO}

Six out of the nine patients serially tested showed an improvement as judged by the shape of their stressstrain curves. Thus the results of their skin tests before treatment (Fig. 3) gave bizarre curves not conforming to recognized patterns and therefore comparable with tethering. After treatment (of minimum duration 4 months), however, these same six patients showed stress-strain curves approaching a normal configuration (Fig. 4), indicating a reduced tethering effect or none. Of great interest was the finding that, at the final follow-up, 9, 10, and 18 months respectively after the end of treatment, three of these patients still had normal stress/strain curves (Table II). In two others (at 12 and 21 months respectively) the curves became abnormal again. The sixth patient was not available for study. The other five patients had persistently abnormal stress-strain curves. Four untreated patients with systemic sclerosis measured serially over similar periods showed no such shift to normality.

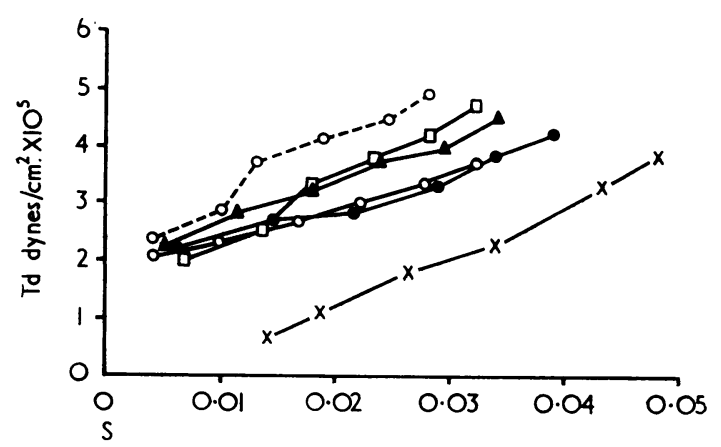

FIG. 4 Results obtained on testing the same six patients shown in Figure 3 after a period of treatment with $D$ penicillamine.

\section{PALM-PRINT AREAS}

The palm-print areas tended to remain unchanged or become worse during the course of treatment (Table II). In four patients, however, significant improvement was apparent. In three of these improvement occurred after treatment had ended; these three patients also maintained normal skin elasticity tests after treatment. The remaining patient whose palm-print area improved during treatment later deteriorated in both skin elasticity and palm-print assessment. The association between changes in vivo in skin elasticity and palm-print areas appears to be close.

\section{SIDE-EFFECTS}

These occurred in eight of the eleven patients. One (Case 8) devloped rash, fever, and severe malaise after taking $150 \mathrm{mg}$. penicillamine for a few days.
Three patients (Cases 1, 9, and 11) had treatment stopped because of persistent proteinuria up to $600 \mathrm{mg}$./day (although other tests of renal function were unchanged). Two patients (Cases 4 and 10) were reluctant to continue taking penicillamine because of persistent side-effects and lack of subjective improvement. One patient (Case 2) had to stop treatment because of gross dysphagia necessitating a gastrotomy.

Rash and/or pruritis was seen in three patients, dyspepsia and/or anorexia in five, fever in four, general malaise in three, proteinuria in three, limb and joint pains in two, and taste disturbances in one. No patients developed blood dyscrasias. It was found that subjective side-effects were usually abated by temporarily lowering the daily dose to tolerated levels and slowly increasing it again. Probably fewer side-effects would have occurred if we had started with lower doses and increased the dosage more gradually. However, rash and disturbances of taste occurred at relatively low dosages.

\section{Discussion}

The trial of any drug in systemic sclerosis is unusually difficult. It is a relatively uncommon disease with an unpredictable course, usually slowly progressive but occasionally undergoing spontaneous arrest or remission, and large numbers of comparable patients are rarely available for paired control studies. Furthermore, objective methods of following the disease process have so far been scanty and it is particularly difficult to quantitate sclerosis of the visceral organs.

The overall clinical result of treatment in this series has been disappointing, with most signs and symptoms showing worsening or no change in the majority of patients. However, by measuring mainly cutaneous manifestations, we have been able to assess the overall progress of this disease. In addition one of us (R.G.) has devised a new semi-quantitative test of dermal tensile properties in vivo (Grahame, 1969) which in systemic sclerosis, can be used to monitor the presence or absence of dermal tethering. This test has shown a definite change towards normality (with normal stress-strain curves) in six out of nine patients, appearing within 5 months of treatment and persisting after treatment finished in three patients. However, once tethering has been eliminated, it ceases to be of use as an index of continuing improvement. Palm-print areas may then become the most helpful method of assessment.

The correlation between palm-print areas, the only other measurement to show significant change, and skin elasticity tests, is interesting, but the reason for the delay in appearance of improvement in palm-print areas is not clear. It is unlikely that the three cases involved had undergone spontaneous. 


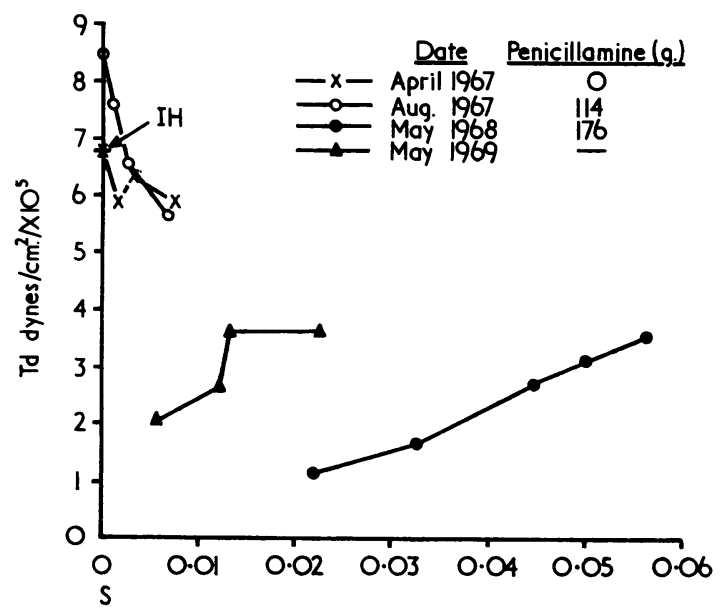

FIG. 5 In vivo stress/strain curves in a male subject $\left(J . O^{\prime} C\right)$ age 56 years suffering from digital arteritis, showing the effect of D-penicillamine therapy with deterioration following withdrawal.

improvement. The delay may be due to a sustained effect of penicillamine, in which case we may expect at a later date to find continuing improvement in the absence of further treatment. We could find no correlation between the effect of penicillamine and age of parient, duration or severity of disease, or dosage of penicillamine.

Abnormal stress/strain curves were found in sclerodermatous patients even when the skin appeared clinically normal; this also occurred in four out of ten patients with digital arteritis but without clinical evidence of cutaneous sclerosis (Fig. 5) (Grahame, 1969).

Improvement in the skin may not necessarily be associated with improvement in the systemic lesions. In particular it is hard to visualize improvement in the severe vascular sclerosis found in some patients. The effect of penicillamine on the collagen of systemic organs is unknown, and this may prove to be a limiting factor in the long-term use of peni- cillamine. Preliminary observations suggesting that skin collagen synthesis is greater than normal in areas of obvious scleroderma, and particularly when this is active (Keiser and Sjoerdsma 1969), suggest that earlier treatment before fibrosis and calcification are advanced might improve the results. obtained.

As in other reports (Scheinberg, 1964; Jaffe, 1965; Henkin, Keiser, Jaffe, Sternlieb, and Scheinberg, 1967; Rosenberg and Hyslett, 1967), sideeffects were frequent and, in some cases, severe enough to necessitate withdrawal of the drug. In view of renal damage due to the drug (Sternlieb, 1966; Rosenberg and Hayslett, 1967) and the absence of clinical benefit, we have regarded the appearance of persistent proteinuria as an indication for ceasing therapy, although in life-saving situations (e.g. Wilson's disease), this side-effect may be acceptable and is apparently non-progressive (Walshe, 1968). We suggest that in future smaller doses of penicillamine should be given for a more prolonged period, thus reducing the incidence of side-effects.

\section{Summary}

D-penicillamine was given to eleven patients with scleroderma, nine of whom were able to continue treatment. Although clinically no benefit was obvious, improvement was found in the skin tethering in six patients by means of a new test and also in the palm-print areas in four patients. This improvement has so far been maintained for up to 18 months after the end of treatment. It is suggested that further trials with penicillamine in a lower dosage and for a more prolonged period might be indicated.

We are grateful to Dista Products Ltd., Speke, Liverpool, for supplying D-penicillamine hydrochloride (Distamine). Some of this work forms part of a thesis submitted by R.G. for the degree of M.D., University of London.

\section{References}

Ansell, B. M., AND Bywaters, E. G. L. (1953) Ann. rheum. Dis., 12, 283 (Finger contractures due to tendon lesions as a mode of presentation of rheumatoid arthritis).

Bluestone, R., MacMahon, M., AND Dawson, J. M. (1969) Gut, 10, 185 (Systemic sclerosis and small bowel involvement).

Godfrey, S., Bluestone, R., AND HigGs, B. E. (1969) Thorax, 24, 427 (Lung function and the response to exercise in systemic sclerosis).

GraHAME, R. (1969) 'In vivo Elasticity of Human Skin'. M.D. Thesis, University of London.

- AND Holt, P. J. L. (1969) Gerontologia (Basel), 15, 121 (The influence of ageing on the in vivo elasticity of human skin).

Harris, E. D., AND SJoerdsma, A. (1966) Lancet, 2, 996 (Effect of penicillamine on human collagen and its possible application to treatment of scleroderma).

Henkin, R. I., Keiser, H. R., Jaffe, I. A., Sternlieb, I., ANd Scheinberg, I. H. (1967) Lancet, 2, 1268 (Decreased taste sensitivity after D-penicillamine reversed by copper administration).

JAFFE, I. A. (1965) Arthr. and Rheum., 8, 1064 (The effect of penicillamine on the laboratory parameters in rheumatoid arthritis). 
- Altman, K., ANd Merryman, P. (1964) J. clin. Invest., 43, 1869 (The antipyridoxine effect of penicillamine in man).

Keiser, H. R., ANd SJoerdsma, A. (1969) Clin. chim. Acta, 23, 341 (Direct measurement of the rate of collagen synthesis in skin).

Nimni, M. E. (1965) Biochim. biophys. Acta, 111, 576 (Accumulation of a collagen precursor in the skin of penicillamine-treated rats).

Pickering, G. W. (1933) Brit. med. J., 2, 1106 (On the clinical recognition of structural disease of the peripheral vessels).

Rosenberg, L. E., and Hayslett, J. P. (1967) J. Amer. med Ass., 201, 698 (Nephrotoxic effects of penicillamine in cystinuria).

Savage, O., Davis, P., Chapman, L., Popert, A. J., Robertson, J. D., and Copeman, W. S. C. (1957) Brit. med. J. 2, 1257 (The clinical course and corticosteroid excretion of patients with rheumatoid arthritis during long-term treatment with corticotropin).

SCheingerg, I. A. (1964) J. chron. Dis., 17, 293 (D-penicillamine, with particular reference to Wilson's disease).

SternLIeb, I. (1966) J. Amer. med. Ass., 198, 1311 (Penicillamine and the nephrotic syndrome).

TANNER, J. M., AND WhitehouSE, R. H. (1955) Amer. J. phys. Anthrop., n.s.13, 743 (The Harpenden skinfold caliper).

Thompson, J. M., Bluestone, R., Bywaters, E. G. L., Dorling, J., And Johnson, M. (1969) Ann. rheum. Dis., 28, 281 (Skeletal muscle involvement in systemic sclerosis).

Tregear, R. T. (1966) 'Physical Functions of the Skin'. Academic Press, London.

Walshe, J. M. (1968) Postgrad. med. J., Suppl. 29, p. 6. (Toxic reactions to penicillamine in patients with Wilson's disease.)

\section{RÉSUMÉ}

Le traitement de la sclérose systémique avec la pénicillamine-D

Une nouvelle méthode pour observer les effets du traitement

La pénicillamine-D a été donné à onze malades atteints de sclérodermie; neuf d'entre les quels ont pu continuer le traitement. Malgré qu'aucun avantage clinique n'était évident, une amélioration a été remarqué dans les attaches de la peau chez six malades au moyen d'un nouveau test et aussi par les empreintes des régions palmaires chez quatre malades. Cette amélioration a été jusqu'ici maintenue pendant 18 mois après la fin du traitement. Il est suggéré que d'autres essais avec la pénicillamine à un dosage moindre et donnée pendant une période plus longue peuvent être indiqués.

\section{SUMARIO}

Tratamiento de la esclerosis sistémica con penicilamina D Un nuevo método para observar los efectos del tratamiento

Se administró penicilamina $\mathrm{D}$ a once pacientes con escleroderma, nueve de los cuales pudieron continuar el tratamiento. Si bien clínicamente no se evidenció ningún beneficio, se notó mejora en la adherencia de piel en seis pacientes por medio de una nueva prueba, y también en regiones de la palma de la mano en cuatro pacientes. Hasta ahora, esta mejoría se ha mantenido por periodos de hasta 18 meses después de terminar el tratamiento. Se sugiere la conveniencia de realizar otros experimentos con penicilamina en menor dosis y por un periodo más prolongado. 